\title{
The Ruptures of Rhetoric: Cool Japan, Tokyo 2020 and Post-3.11 Tohoku
}

\section{PEPI RONALDS}

Monash University

\section{ABSTRACT}

Policymakers in Japan have adopted a discourse to link the Tokyo 2020 Olympics to the recovery of Japan's northern Tohoku region following the March 2011 triple disaster (3.11). This discourse has created a dissonance between 3.11-affected communities, policy-makers and wider Japan. To understand this dissonance, this article explores the implicit agendas behind Japan's Olympics efforts (such as positioning sports as a facilitator and symbol of recovery), its Cool Japan initiative (as a nation-branding and nation-building strategy) and other actions (such as labelling the 2020 event 'the Reconstruction Olympics'). It then analyses the opinions of people from affected areas, gathered through interview research and from popular media, to demonstrate that the use of recovery rhetoric to promote the Olympics is being poorly received among some in 3.11-affected communities. Community concerns circle around availability of construction resources as well as the fact that recovery is not yet complete. This article contends that the events of 3.11, combined with the pursuit of the Olympics, has effected changes in the social imaginary and in regional ideas of belonging among 3.11-affected communities.

\section{KEYWORDS}

3.11; contemporary; Cool Japan; nationalism; rebuilding; recovery; Tohoku; Tokyo 2020 Olympics
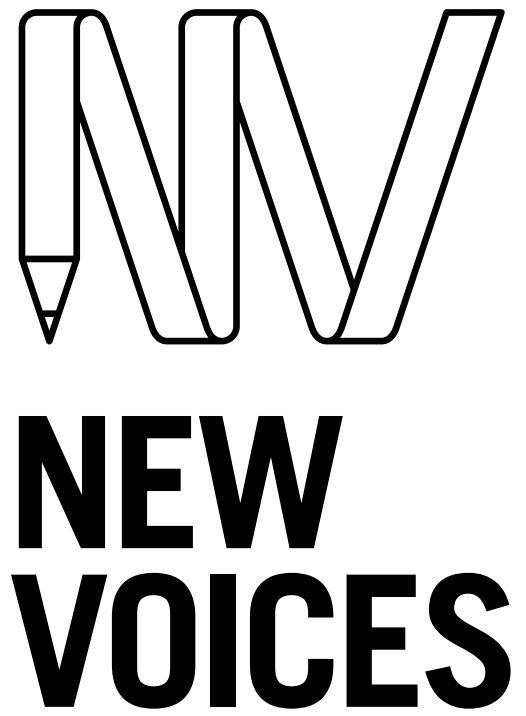

IN JAPANESE STUDIES

JAPANFOUNDATION \& BRINGING JAPAN TO YOU

To link to this article: https://doi.org/10.21159/nvjs.11.02

\section{ISSN 2205-3166}

New Voices in Japanese Studies is an interdisciplinary, peer-reviewed journal showcasing the work of emerging scholars with ties to Australia or New Zealand and research interests in Japan.

All articles can be downloaded free at newvoices.org.au

(c) The Japan Foundation, Sydney and Pepi Ronalds, 2019

\section{(c) $(1)$}

This work is licensed under a Creative Commons Attribution-NonCommercialNoDerivatives 4.0 International License. 


\section{INTRODUCTION}

At the closing ceremony of the Rio Olympics in August 2016, Japanese Prime Minister Shinzo Abe made an appearance. He rose from a giant green pipe costumed as one of Japan's most popular cultural exports: Super Mario. Abe's appearance was heralded with a short, polished big-screen film production that elicited loud cheers from the stadium crowd. In the film, the nation's top athletes trained alongside popular attractions and tropes like Tokyo Tower and the shinkansen. There were images of skyscrapers, Tokyo station, cherry blossoms and the Ginza. Interspersed with these 'real-world' images were scenes from anime and appearances from cartoon characters like Hello Kitty, Pacman, Mario and Doraemon. The film portrayed Abe's journey from Japan to Rio, morphing into a cartoon Mario en route. Enabled by a tool from Doraemon's $4 \mathrm{D}$ pocket, the cartoon Mario-Abe shot into a tunnel to Rio through the centre of the earth. In the real Rio Olympic stadium-where the crowd was hyped by a countdown, flashing lights and the Super Mario game's shrill Power Up jingle-the costumed Abe appeared from the pipe and confidently waved Mario's red hat. He then raised a red ball high in his outstretched arms, and with that, the symbolic Olympic handover from Rio to Tokyo was complete.

The film covered all the cultural tropes foreign consumers expect from Japan-from the old-style magic of traditional sights, to its embrace of technology and animated characters. In appropriating Mario, Doraemon, Hello Kitty and Pacman (all symbols of Japan's creative exports), Abe was engaging a wider national scheme known as Cool Japan. According to Japan's Cabinet Office website, the concept of Cool Japan "covers all aspects of Japanese culture from subcultural products, such as manga and Japanimation, to traditional cultural heritage" (Cabinet Office 2014, 2). Described as "an initiative to further strengthen the ties between Japan and other countries (in such areas as economics, culture, and diplomacy)" (Cabinet Office n.d.), Cool Japan is part of a nation-branding effort aimed at positioning Japan and its cultural exports in the global marketplace (Valaskivi 2013). Cool Japan was first applied as a slogan to Japan's nation-branding projects in the mid-2000s (Valiskivi 2013, 485), and continues to be described variously as a 'policy', 'strategy' and 'initiative' (METI 2016; Cabinet Office n.d.). Policy-makers' primary aim in promoting Cool Japan is nation branding that "can be seen as a conscious effort to influence the social imaginary of a nation" (Valaskivi $2013,486)$. 'Social imaginary' is drawn from the work of Taylor (2004), who describes it as:

the ways people imagine their social existence, how they fit together with others, how things go on between them and their fellows, the expectations that are normally met, and the deeper normative notions and images that underlie these expectations.

(23)

As an exercise in promoting Cool Japan, hosting the 2020 Olympics is an effort towards both nation-branding and nation-building. But what is the effect of the 2020 Olympics effort (and its attendant rhetoric) on the social 
imaginary of disaster-affected Japanese citizens in the context of Japan's recent history? The following discussion explores this question.

\section{ELEPHANT IN THE STADIUM}

Earlier in the ceremony an ambiguous nod was made toward what was, for many, the elephant in the stadium. The words "Thank you" were displayed in dozens of languages, including "Thank you for your support" in English. While nothing more was included in the display itself, Australian broadcast commentator Joanna Griggs drew a direct line between the words and the calamity known as 3.11: "The Japanese, taking the opportunity to thank the people of the world for their support following the horrendous earthquake they suffered from in March 2011-that caused so much destruction, loss of lives, and injuries" (Griggs in Wilson, 2016). Here Griggs acknowledges the triple disaster-an event which the people of Tohoku had borne the brunt of just five years before. ${ }^{1}$

3.11 comprised a magnitude 9.0 earthquake, a tsunami that reached heights of over 40 metres and inundated 560 square kilometres, and a nuclear meltdown at the Tokyo Electric Power Company's (TEPCO) Fukushima Daiichi nuclear power plant, sending a plume of radiation through the area. As a result of the disaster, 15,896 people lost their lives and 2,536 are still missing (National Police Agency 2018). On 24 April 2011 (within six weeks of the disaster) there were over 340,000 evacuees (Reconstruction Agency 2011); a year after the Rio closing ceremony-five years after 3.11-that number had less than halved to 119,000 (Reconstruction Agency 2017). Two years out from the Tokyo 2020 Olympics and seven years after 3.11, 65,000 people were still without permanent homes (Reconstruction Agency, 2018a). At the time of writing, the number of people still living in temporary housing is 57,000 (Reconstruction Agency, 2018b).

Although the handover at the closing ceremony in Rio only minimally acknowledged 3.11, more direct connections have been made between the two events within Japan. At times, domestic politicians have labelled the Tokyo Olympics 'the Reconstruction Olympics' (復興五輪; fukkō gorin) and many key players in the Tokyo Olympic effort have positioned sports as a facilitator and symbol of recovery. ${ }^{2}$ For example, in an English-language press release about the forthcoming Torch Relay and plans for the relay to pass through Tohoku, John Coates (IOC Coordination Commission Chair for Tokyo 2020) said:

We hope that this symbolic act will underline the Olympic Movement's support for the citizens of [the affected] regions, as well as allowing them to show the watching world the progress that they have made in rebuilding their lives and inspiring the local children through the Olympic values.

(IOC 2018) 
By hosting a so-called 'Recovery Olympics' alongside the Cool Japan campaign, the 2020 Olympics can be seen as an effort to influence the social imaginary of both the Japanese nation and international audiences. However, what effects, if any, are these efforts having on the social imaginaries and perspectives of those in the north? Drawing on individual voices expressed in interview research as well as others from popular media, this article contends that despite efforts on the part of Olympics organisers and Japan's political elites, the nation-building aspect of the Tokyo 2020 Olympics is failing for many in the region directly affected by 3.11 .

\section{METHODOLOGY AND LIMITATIONS}

Since 2014 I have conducted annual, open-ended and semi-structured interviews with individuals in Miyagi prefecture to understand how their lives have been affected by $3.11 .^{3}$ The interviews are part of a larger project: a creative nonfiction manuscript which aims to document the longer-term challenges, hopes and achievements of these individuals. ${ }^{4}$ Because of the nature of creative non-fiction-where limitations are often explicitly documented in the storytelling-my process allows for more fluidity in the data gathering than social-science disciplines.

The interviewees were recruited via my professional and personal contacts in Miyagi and later through snowballing introductions. They include people whose homes and/or communities were inundated by the tsunami, as well as people who work or otherwise participate in reconstruction in either volunteer or paid roles. My most recent interviews were conducted in October 2018. I used interpreters to conduct the interviews, which are audio-recorded and partially transcribed by myself.

I have conducted over 80 interviews, increasing and decreasing my pool of interviewees on a needs basis. Around 40 of these interviews were conducted with a core group of 12 or so individuals who were interviewed annually over multiple years. Approximately $80 \%$ of the interviewees are men over 40 years of age, with a little under $50 \%$ being men over 50 years of age. The gender and age profile of this group is an unintentional product of the process of recruiting participants (primarily through introductions), the aging demographic of the region and historical practices which make it more likely for older men to hold spokesperson positions within organisations and communities. I approached analysis of the interviews with an awareness of the biases which such a skewed participant profile may reflect.

In 2014, an interviewee volunteered his perception that soon after the winning Olympic bid was announced in 2013, the number of construction vehicles present in his district was visibly reduced (Kogure 2014). After hearing this

\footnotetext{
3 I have limited my research to Miyagi, deliberately omitting Fukushima as a focus. This is not to discount the monumental challenges faced by communities in Fukushima, but to recognise that there are already many other accounts about their experiences available in English. For a more detailed understanding of the events around the meltdown, see Cleveland's 2014 article, "Significant Breaking Worse" and Willacy's 2013 book, Fukushima: Japan's Tsunami and the Inside Story of the Nuclear Meltdowns.

4 Creative nonfiction is a form of literary storytelling which Gutkind defines as "factually accurate prose about real people and events_in a compelling, vivid, dramatic manner" $(2012,6)$.
} 
comment, I specifically sought the opinions of other interviewees in 2015 with the question, 'In what ways, if any, has the 2020 Olympics work helped or hindered your community in recovery? ${ }^{25}$ Opinions on the Olympics thereafter comprised one of about a dozen different topics discussed each year with the core group of people. By 2018 the Olympics question had become, 'How are you/is your community feeling about the so-called Recovery Olympics at this stage?'

My intention is to report my interviewees' perceptions rather than critique their positions. While the quotes used in this paper generally express negative sentiments, most of my interviewees prefaced their response to questions about the Olympics by acknowledging beneficial outcomes such as enhanced tourism and nation-branding, as well as the potential for sports to bring people together and uplift a nation after calamity. But with the exception of one person, these outcomes have not swayed them from questioning the Japanese government's pursuit of the Olympics when so much practical recovery work still needs to be achieved.

\section{LITERATURE REVIEW}

\section{Olympics: Showcasing a Nation}

The act of hosting the Olympic Games is an opportunity for governments to showcase a nation in the global context, as well as create "a source of national and civic pride" (Martin 2000, 19). The Olympic Games promote a particularly heightened sense of nationhood, and are seen by governments as an opportunity to reconsider and foster national identity (Berry 2013, 87). Thus, in the lead-up to and during the Olympics, images and rhetoric circulate in the service of national goals, promoting legacies and nation-brands. The term 'Recovery Olympics' as applied to Tokyo 2020 appears to meet these goals, marking the event itself as a legacy and helping international and national audiences to imagine Japan as recovered from 3.11. But as evacuee statistics and other evidence shows, in 2018 Tohoku had not yet overcome 3.11.

\section{National Identity}

By defining a nation as an invention which is limited, sovereign and imagined as a community, Anderson $(1983,6)$ helps to explain why a nation might host the Olympics despite a challenge like recovery from 3.11. "Imagined communities" can be informed by the official narratives of dominant groups (Anderson 1983, 101) and media representations help to circulate them (37-46). In the context of Tokyo 2020, the Japanese national government can be considered a dominant group cultivating an imagined community by circulating the image of Japan as a post-recovery Olympic host. Taylor's concept of the social imaginary builds on Anderson's work by exploring how "ordinary people 'imagine' 
their social surroundings" and illuminating how this "makes possible common practices and a widely-shared sense of legitimacy" (Taylor 2004, 23). Taylor's work recognises the contribution that our everyday interactions make to our imagined selves and highlights how everyday practices can inform these (despite the efforts by dominant groups which Anderson identifies). Together, Taylor and Anderson demonstrate the porousness of identity, and how associations are influenced by the push and pull of narratives in personal and wider social orbits. This tug is also visible in Japan's efforts towards constructing a particular imagined community and social imaginary pertaining to the 'Recovery Olympics' and Cool Japan.

\section{Human Security and Resilient Nationalism}

Part of what informs the social imaginaries of those directly affected by 3.11 is their experience of the aftermath of the disaster. Shani contends that the events of 3.11 "revealed the inability of a modern, industrialized nation-state to protect its own citizens, shattering the public's trust in the government" $(2016,129)$. This trust was largely undermined due to a failure in protecting the human security of those affected. ${ }^{7}$ Shani's examples of this failure include the 150,000 people still in temporary housing and the limited compensation provided to those displaced by the radiation (Shani 2016, 133). He argues that after 3.11, '"racialized' biopolitical divisions between 'inside' and 'outside', which had hitherto been used to distinguish colonial and ethnic minorities, became (re)inscribed within the Japanese nation" (2016, 132; italics original). ${ }^{8}$ According to Shani, the government's widely criticised response to the disaster created a "space for the articulation of a discourse of resilient nationalism, which underpins the current Abe administration" (2016, 129; italics original). This nationalism was expressed in the catchphrase Ganbaro Nippon ("Let's do our best, Japan”), which became a popular slogan of encouragement from across Japan towards those affected. As Shani suggests, this phrase "abnegates all responsibility from the state for [the protection of residents in disasterhit areas] and displaces it onto the affected communities themselves" (2016, 130). A part of the response to that abnegation was the appearance of localised Ganbarō slogans (Shani 2016, 136). As will be discussed below, these placespecific slogans shone a light on who exactly was doing their 'best'. Was it the entire nation? Or those whose human security was affected by the disaster? Shani's consideration of human security and resilient nationalism will be applied in this article to understand the ways in which national and local perspectives have diverged.

\section{Nation Branding, Cool Japan and Soft Power}

While resilient nationalism is not necessarily a formal strategy employed

\footnotetext{
7 The United Nations summarises human security as "the right of all people to live in freedom and dignity, free from poverty and despair...from fear and...want, with an equal opportunity to enjoy all their rights and fully develop their human potential" (United Nations, 2005, 31).

8 Shani writes that despite constitutional rights to equality in Japan, institutional discrimination along "racialized" lines has historically existed towards minority 'outsiders' such as "Buraku and Ainu; people and descendants of Japan's former colonies in Korea and China; foreigners and migrants from other parts of Asia and the rest of the world" $(2016,132)$. Paraphrasing Satō, Shani says these "racialized" others were "the referent objects for human security, as a tool of Japanese foreign policy” (Satō 2007 in Shani 2016, 129).
} 
by the Abe administration, Cool Japan certainly is. Cool Japan is a form of cultural diplomacy, or soft power, which leverages Japan's creative assets in the global marketplace. The concept came to the fore amidst Japan's economic collapse of the late 1990s and the growing realisation that promoting Japan's creative products could help its struggling economy (Daliot-Bul, 2009, 247). Cool Japan has been linked by Daliot-Bul (2009), Valaskivi (2013), Iwabuchi (2015) and others to journalist McGray's 2002 Foreign Policy article, Japan's Gross National Cool. In the article, McGray celebrates Japan's success in making "deep inroads into American culture" $(2002,46)$ via creative industry products. "Instead of collapsing beneath its political and economic misfortunes, Japan's global cultural influence has only grown," writes McGray $(2002,47)$. As the introduction to this paper demonstrates, Cool Japan has been deployed as a tool to promote the 2020 Olympics.

The term 'soft power' is drawn by McGray (2002) and others (Daliot-Bul 2009, 248; Iwabuchi 2015, 422) from the work of Joseph S. Nye, Jr. Daliot-Bul writes, "in a great shift from the more traditional power structures, 'soft' power derives mostly from intangible resources such as culture and ideology rather than from military action or economic incentives" $(2009,248)$. Cool Japan is an exercise in soft power. And in drawing upon and applying Cool Japan resources in its marketing campaign, the Tokyo 2020 Olympics can be seen as an effort in soft power and transnational nation branding.

\section{Nation Building}

Scholars concur that outward-looking policies like Cool Japan are also efforts in inward-looking nation building. Iwabuchi, for example, writes that:

Cultural diplomacy maneuvered in conjunction with nation branding is not only directed externally, but also internally, as a tool for inculcating a narrative of the nation and a sense of national belonging.

$(2015,427)$

Daliot-Bul notes that initiatives like the Japan Brand Strategy, of which Cool Japan is a part, are "seen as a means to revitalize patriotic pride and recruit those patriotic feelings for national ends" $(2009,260)$. Similarly, Valaskivi observes that while policies like Cool Japan aim to influence the international brand, their influence domestically cannot be ignored:

a nation brand [is] much more than marketing measures directed towards other countries. It becomes a part of the social imaginary in the construction of national identity, at least among the elites undertaking the branding task.

(2013, 490; my italics)

Valaskivi's "elites undertaking the branding task" includes politicians, bureaucrats and the socially powerful, such as the representatives from private and government sectors who comprised the Cool Japan Advisory Council (CJAC). Iwabuchi (2015), Daliot-Bul (2009) and Valaskivi (2013) all demonstrate how outward-facing nation branding is intrinsically linked 
to inward-facing nation-building. To this end, not only are the Tokyo 2020 Olympics an effort to showcase Japan to the world, but also to develop national pride and belonging within Japan.

\section{Creating a New Japan}

In May 2011, the CJAC produced a proposal document, Creating a New Japan, which was available on the Ministry of Economy, Trade and Industry (METI) website (METI 2011). The Creating a New Japan proposal "connects enhancing the 'Japan Brand' with rebuilding the nation after the Great East Japan Earthquake" (Valaskivi 2013, 485). Work on the proposal had commenced in November 2010, prior to 3.11, but the version published in May 2011 "began by tying branding efforts to recovery and rebuilding" (Valaskivi 2013, 487) and documented initiatives to help 3.11-affected areas (METI 2011, 15). As this example shows, the national government was quick to leverage the Cool Japan strategy as part of a recovery rhetoric. But the Creating a New Japan proposal also noted how 3.11 had "severely damaged consumers' perception of Japanese products...and [was] affecting exports...as well as the number of overseas tourists to Japan" $(2011,4)$. Because of this, the document reads, "Japan must work quickly to dispel any short-term negative impact...tell the world of the unshakably strong qualities of Japan...[and] send out messages that utilise the power of sympathy" (METI 2011, 12). One of the document's key goals was "Overcoming the Earthquake [by] restoring the shine of the 'Japan Brand"' $(2011,1)$. Therefore, while Japan is using the Olympics as a platform for its international Cool Japan nation-branding effort, it is also drawing connections between the Olympics and the events of 3.11 through devices such as the Creating a New Japan proposal and the 'Recovery Olympics' moniker.

\section{The Recovery Olympics' Legacy as Cool Japan}

In using these devices, the Japanese government and the IOC are deploying what Tomlinson calls a "legacy discourse" (2014, 138): a narrative "[d] eveloped as a principle to justify the Olympic phenomenon at a time of crisis and survival...[and] turned into a rhetorical tool" $(2014,139)$. Tomlinson's work explores a variety of "legacy claims" $(2014,137)$, including the bid for the Tokyo 2020 Games. Tomlinson's conclusion can be read as a commentary on the Tokyo 2020 project: "legacy rhetoric pervades contemporary Olympic discourse despite strong evidence on many fronts that the harsh realities contradict the legacy hopes and aspirations" $(2014,151)$. In the case of the Tokyo 2020 Olympics, the legacy rhetoric includes the label 'Recovery Olympics' as well as previously cited claims such as "support for the citizens of [the 3.11-affected] regions" (Coates in IOC 2018).

Valaskivi argues that the "circulation" of nation branding allows "a particular social imaginary [to be] formulated, represented, and reproduced and transformed in different localities" $(2013,485)$. Consequently, how the

(2)


Olympics efforts are imagined in one region of Japan might well be different in other regions. Tomlinson's work casts doubt on the government's stated intentions to support post-3.11 recovery through the Olympics. The sentiments of my interviewees also reflect this view: they see little reason for the Olympics to be held in Japan in 2020 because, seven years on from the disaster, recovery in 3.11-affected regions is still underway.

\section{Disaster Recovery}

The concept of disaster recovery encompasses three key and interrelated meanings: "the restoration of normal community activities that were disrupted by disaster impacts", "a phase in the emergency management cycle that begins with stabilization of the disaster conditions" and "a process by which the community achieves the goal of returning to normal routines" (Lindell 2013, 812; my italics). In the context of Japan - a highly industrialised nation-one can attach 'fulfilling the needs of human security' to Lindell's description of "returning to normal routines". At the very least, therefore, 'recovery' from 3.11 can be understood to involve practical things such as permanent housing for those who lost their homes and employment for those who lost their livelihoods. Nonetheless, when the Tokyo 2020 Olympics were awarded in 2013, recovery at these most basic levels had not been achieved. ${ }^{9}$ Indeed, by the time of Abe's performance at the Rio 2016 closing ceremony, and as this article is being written (in 2018), the application of Lindell's definition shows that recovery in Tohoku is still a long way off.

\section{RUPTURE}

There were economic consequences to the events of $3.11 .^{10}$ Not only were places of business and production completely destroyed by the earthquake and tsunami, but infrastructure such as ports, roads and railways were also undermined. Global and national supply chains were disrupted and the loss of life, heartbreak and consequent migration from affected towns resulted in decreased productivity and population drops. But the CJAC's (previously cited) post-3.11 goal of restoring Japan's national brand demonstrates a divergence between the concerns of disaster-affected communities and Tokyobased political elites. While the elite polished the 'Japan Brand', hundreds of thousands in evacuation centres (Reconstruction Agency 2016, 10) dealt with traumatic experiences and faced uncertain futures.

This was not the first divergence of elites from survivors pertaining to 3.11. While Japan's Self Defence Forces (SDF) were mobilised within an hour of the tsunami, Richard Samuels (2013) writes of the many later missteps and bungles that Prime Minister Naoto Kan (Democratic Party of Japan) and his government wrought in the immediate aftermath (9-16). These include inefficiency through micromanaging, lack of clarity between headquarters (e.g., between Headquarters for Special Measures to Assist the Lives of Disaster

9 For example, in 2013 there were still 282,000 evacuees living in temporary housing (Reconstruction Agency 2013, 1).

10 For an initial overview of the economic impacts, see Komine (2011).

Pepi Ronalds

New Voices in Japanese Studies,

Vol. 11, 2019, pp. 26-46 
Victims and the Recovery Agency), a "poisoned political atmosphere" and inadequate circulation of important information (2013, 10-15). The government's failures pertaining to the unfolding situation at TEPCO's Fukushima nuclear power plants are explicitly documented by the National Diet's Fukushima Nuclear Accident Independent Investigation Commission, which states in an official report that " $[\mathrm{t}]$ he government failed in its responsibility to the public" (NAIIC 2012, 35) and that "the government, the regulators and TEPCO...effectively betrayed the nation's right to be safe from nuclear accidents" (16).

Events like those at TEPCO's plants, as well as the scope of the disaster, meant that the human security of those directly affected on March 11, 2011 and in the immediate aftermath was undermined, with the result that "faith in the state was badly shaken" (Shani, 2016, 136). While Aldrich $(2017,39)$ notes that a "trust deficit" between the Japanese and their government is not a phenomenon unique to post-disaster Japan and was evident as early as the 1980s, he recognises that the government's response to 3.11 "undermined what little trust citizens had in their elected officials and in their bureaucracy" (47). Shani concurs, observing that the disaster "revealed the inability of a modern, industrialised nation-state to protect its own citizens... and in so doing, endangered national cohesion" $(2016,129)$. While the moment of 3.11 was a disaster in itself, the government's response in its aftermath aggravated the difficulties being experienced by those affected.

A nation-branding (and nation-building) event such as the 2020 Olympics may present itself as a perfect solution to a lack of national cohesion. Yet, far from defining a social imaginary shared across Japan, many in Tohoku have felt an ongoing discord between their own recovery needs and the (in)action and rhetoric of their national government as it pertains to the resources allocated to the Olympics. Tohoku communities were disappointed with the government's response in the immediate wake of the disaster (see Shani 2016; Samuels 2013). As will be outlined below, more recently they have been disappointed by the government's decision to pursue the Olympics agenda, and by its efforts to leverage recovery rhetoric within that pursuit.

\section{RHETORIC}

A video uploaded to YouTube by the Tokyo Metropolitan Government in 2016, titled See You in Tokyo and Tohoku 2020, exemplifies recovery rhetoric being employed as part of the Olympics message. The video starts with audio and images showing the destruction wrought by 3.11. Initially backgrounded by solemn piano music, the tone significantly shifts within a few moments and the video transforms. Uplifting music plays alongside spectacular images of fishing boats resplendent with tairyō-bata (大漁旗; flags traditionally used signify a big haul) on a clear sunny day. As the boats glide in formation across a vivid blue sea, the traditional tairyo-bata are replaced by flags of foreign countries billowing in the wind. Soon, the video shows children: in gyms, baseball fields and swimming pools, smiling, laughing and playing. "When 
we were looking for a way forward, it was sport that gave us the strength to find it," a narrator says in English. One of the children talks about sport and friendship, and wheelchair tennis player Shingo Kunieda reinforces a message of ongoing connection between people (in Japanese, with English subtitles). Then, the narrator returns: "Sport helped us regain a sense of normality, and take a step towards a new future." After more smiles, waves and "arigatō"s the music hits its peak and the video ends with four dramatically delivered words: “Tohoku. Japan. The World." (TMG 2016).

Another video on the same channel made after the disastrous earthquake in Kumamoto, April 2016, echoes the same sentiment. "Sport teaches us the joy of meeting people, forming bonds and sharing a strong passion," it claims (TMG 2018). This video is titled See you in Tokyo and Kumamoto in 2020. The implication in both of these videos is that the Olympics efforts are having (and can have) a positive effect on recovery. While there may be some recovery benefits of sports, (and some Tohoku residents may hope that the Olympics will bring visitors and tourism income), most of my interviewees have drawn links between the Olympics announcement and slowing recovery in Tohoku, as will be discussed below.

\section{COMPETING CONSTRUCTION}

The limited availability of construction resources (see Kurtenbach 2014) is central to the tensions between those in disaster-affected areas and the national government's pursuit of the Olympics. In Tohoku, 560 square kilometres of coastline was devastated and the entire region's infrastructure was severely damaged in the 3.11 disaster. The demand for construction in devastated areas combined with demand for Olympics-related construction saw construction costs increase by at least 30\% in 2016 (Japan Property Central 2016), marking the highest cost increase Japan had experienced in this industry since its economic bubble burst in the early 1990s (Nikkei 2014). Given the ongoing need for human security in affected communities, the construction resource battle has put a wedge between the national government's nation-branding/nation-building aspirations and Tohoku identities. As the Mayor of Rikuzentakata, Futoshi Toba, said in 2016: "If construction [of Olympics venues and housing/infrastructure in areas affected by 3.11] overlaps, there won't be enough workers and wages will rise, making houses more expensive" (Lies 2016). ${ }^{11}$ He questioned why the government chose 2020 for the Olympics: "I think they could easily have hosted them four years later" (Lies 2016). In some places-including Kesennumathe delays in obtaining construction resources have compounded difficult living conditions, with one interviewee noting that some evacuees were forced to move from one temporary housing unit to another while waiting for permanent homes to be built (Komatsu 2018). ${ }^{12}$

Rather than embracing a national social imaginary of Japan as a post-recovery Olympic host on the world stage, comments from my interviewees suggest that in Miyagi at least, the Olympic effort is creating a dissonance in the social 
imaginary between those in 3.11-affected areas and Tokyo. For example, Ishinomaki resident Yōko Suzuki (who was a school principal at the time of the 3.11 disaster), understands that the Olympics is significant and meaningful as a global sporting event. However, she cannot see a practical connection to recovery: "It seems to me that 'recovery' is a label attached to the Olympics just for the convenience of politicians. I find it completely intolerable" (2018). ${ }^{13}$ She believes the government should be focusing more on the practicalities of recovery rather than the symbols and meanings of an Olympic pursuit. She makes the point that eight years after the disaster, problems in affected areas of Tohoku remain (2018).

Similar sentiments have been expressed by other regular interviewees from across Miyagi prefecture. "[Hosting the Olympics] may well have some major benefits, but as someone from a disaster-stricken area, I don't think it's going to bring us anything positive" says Shiryū Okano, a resident of Kesennuma and curator at its Rias Ark Museum of Art (2017). ${ }^{14}$ Another Kesennuma resident questions the true meaning of the Olympic efforts. Takashi Tsukamoto, who works in post-disaster community building, says: "[Government and Olympic decision-makers] just slap 'recovery' on the front there-for no real reason [...]. To me this kind of language reveals a major problem: it seems that there is little awareness in national policy or among the people in government that we still need to do a lot more for recovery, rather than just saying that we will show people how much we have recovered already" (Tsukamoto 2017). ${ }^{15}$

Concerns are not only directed towards policy-makers and their rhetoric but also toward representations in the media that fuel misconceptions about what is happening in Tohoku. Okano, for example, feels that the media tends to promote success stories and downplay the massive recovery work that is yet to be done: "The best thing would be to give the people of the world a realistic view of things, to also share some of the outstanding issues-not to paint recovery as a completed picture" (2017) ${ }^{16}$ He makes a further point: "If at the Olympics [the media] just try to make it out like we have already recovered, there would be concern about what would happen afterwards, and people would think the media don't know or care what it's really like up here. It would be a negative step" (2017). ${ }^{17}$ Indeed, he believes that sugar-coating problems would likely frustrate locals and possibly affect what kind of assistance is provided to the area (2017).

A year after the interview with Okano, infrastructure recovery was still underway in Okano's town of Kesennuma, and a representative of the municipality confirmed that around 100 households still remained in temporary housing (Murakami 2018). For Okano, painting a rosy picture 
of the disaster-hit areas in messaging for the Tokyo Olympics has major implications-not only in terms of the kind of assistance that is provided to areas still recovering, but also for affected people's perceptions of their own situation. He is worried that some individuals who are still struggling might feel that everyone else is happy and fully recovered except them (Okano 2017).

Although the national government is deploying the Olympics as a nationbuilding (and nation-branding) tool, the above comments suggest an unintended response. Many in these disaster-affected communities do not feel unity with this particular nation-branding message. Such perspectives demonstrate the limitations of both nation-branding (when human security is undermined) and the 'resilient nationalism' encapsulated in the Ganbarō Nippon slogan. They also provide clues to why the Ganbarō slogan was ultimately localised.

\section{'Ganbarō' Atomised}

In the months that followed 3.11, Ganbarō slogans were widely visible on paraphernalia (posters, stickers, wristbands, bumper stickers, t-shirts, etc.) and through popular and social media. The Ganbarō Nippon catchphrase (discussed earlier) became a rallying cry-a symbol of the support people across Japan hoped to express towards those affected. But as Shani writes, "Slogans such as Ganbarō Nippon rang particularly hollow in the immediate aftermath...for irradiated communities and residents of the tsunami-affected areas who had lost everything to the 'black waters' while political elites were preoccupied with 'containing' the crisis" (Shani 2016, 136). Rather than seeing national unity with Ganbarō Nippon, those in 3.11-affected areas localised the Ganbarō message (Shani 2016, 129-140). In the north, Ganbarō Tohoku ('Let's do our best, Tohoku') was arguably more prolific than the original Ganbarō Nippon. Often Tohoku-oriented Ganbarō paraphernalia aligned with local tropes such as the Pacific League's Tohoku Rakuten Golden Eagles baseball team or with historical figures like Date Masamune, the founder of Miyagi prefecture's Sendai City. As 3.11-affected areas tried to recover, the Ganbarō message further atomised. A person could buy a Ganbarō Matsushima T-shirt at the newly cleared Matsushima port, for example. Town-specific messaging demonstrates how atomised the Ganbarō message became.

As early as April 2011 an Ishinomaki local, Kenichi Kurosawa, created a billboard in the spot where his home once stood. It read, 'Ganbarō! Ishinomaki' (Taylor 2011). Shani reminds us that the localised sign was "a poignant reminder that the isolated fishing villages and farming communities of the north-east and not the 'imagined community' of Japan were the real victims of 3.11" (2016, 136-37). But even the localised sign has been appropriated for wider imagined meanings, to be discussed below.

\section{RESISTANCE}

In the former Kadonowaki-chō school district of Ishinomaki (where the 'Ganbarō! Ishinomaki' sign stands), appropriation and dissonance has grown. 
Even before it was completed, the Ganbarō! Ishinomaki sign became a topic of international news (see Chiba 2011), and it has since become a popular spot on disaster tourism trails. ${ }^{18}$ While ostensibly a symbol of encouragement, the sign can also be seen as a marker of government indifference for those who live nearby, as an interviewee observes. "The mayor has never been here ... hardly any senior officials or politicians have come [to our district]. The only time the mayor comes is if there are dignitaries from overseas. He places a wreath at our Ganbarō sign, visits the primary school ... he only comes when someone like a president visits" (Honma 2014). ${ }^{19}$ This comment came in the context of one community asking its mayor to consider their voices in plans to rebuild the neighbourhood-a request which was initially denied, creating a source of frustration at the time. Eventually, the neighbourhood's energies were exhausted, and the community accepted the neighbourhood rebuilding plan as created by the municipal government-despite the fact that the area's new post-disaster streets lack the social, service and business infrastructure (such as a post office, bank, medical services and convenience stores) that had formerly sustained the neighbourhood (Honma 2016). ${ }^{20}$

Initially, some in Ishinomaki responded to the Olympic pursuit alongside the national government's nation-branding rhetoric, identifying an opportunity. For example, the former neighbourhood of Minamihama on the coast of Ishinomaki (zoned uninhabitable after the disaster due to the tsunami) is to be made into a memorial peace park. Locals envisaged international Olympic visitors making a pilgrimage to the park. Yet by 2014 , this vision was fading. An NPO worker at the time recalls: "As soon as the decision was made to hold the Olympics in Tokyo [September 2013], the trucks started disappearing and the numbers of companies doing [recovery-related] construction decreased" (Kogure 2014). ${ }^{21}$ He confirmed the observation by informally surveying construction company associates he had at the time and reiterated this observation again in 2018, concluding: "There is absolutely no purpose whatsoever for [the government] to be calling these the 'Reconstruction Olympics'. I consider it an outrage" (Kogure 2018). ${ }^{22}$

Already discontented by the national government's inability to provide security during and since the disaster, many in 3.11-affected areas are vocal in opposing the Olympics. Some opposition is expressed via popular and social media. Frustrations are voiced in news stories. ${ }^{23}$ Japanese-language searches on social media using keywords such as 'Tohoku' (東北) and 'Recovery Olympics' (either “復興五輪” or “復興オリンピック’) add more opposing voices. In 2018, the Kahoku Shinpō-a Sendai-based newspaper focussed on the Tohoku region-put numbers behind the idea of an unwelcome Olympics. They surveyed 1,475 people from affected areas, inland areas and wider

18 Disaster tourism, also known as 'dark tourism', refers to the act of visiting/touring places that have been affected by a disaster of some kind.

19 「市長も一回も来たことがないし…上層部、幹部とか政治家もここに来た人はほとんどいません。市長が来る

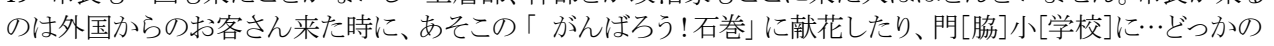
ほら…大統領とか来たときに一緒に来るだけで。」

20 The same mayor officiated at a ceremony to declare the area's reconstruction efforts complete in 2018 (Honma 2018).

21「オリンピックが決まった瞬間からトラックがいなくなっり、引きあげたり、そういう工事をやる、企業さんが少 なくなっています。」

22 「私はまるっきりないと思っていました。名前だけの復興五輪というのが使われるのは心外ですね。」

23 For examples in English, see Alexander (2013), Lies (2016) and Nagano (2016). For Japanese-language

examples, see Kahoku Shinpō (2017), Mainichi Shinbun (2016) and Morita (2017). 
Tohoku, asking the question, "Do you think the 2020 Olympic Games will be useful for the reconstruction of disaster areas?", and published the results. ${ }^{24}$ Across the region, 52\% agreed that it would not be helpful (役に立 たないと思う). The second-largest group comprised 30\% who neither agreed nor disagreed that it would be helpful (どちらともいえない). Only 12\% agreed it would be helpful (役立つと思う), with the remaining 6\% uncertain (わから ない) (Kahoku 2018, 16). Noting that the Tokyo Olympics is being positioned as the 'Reconstruction Olympics', the survey then asked, "Do you think the 'Reconstruction Olympics' philosophy is clear?", to which 63\% responded that it was not (明確ではない) (Kahoku 2018, 17). ${ }^{25}$

Valaskivi notes that "an attempt to portray a particular image towards those outside Japan leads to internal efforts to hide unwanted and uncomfortable elements that do not fit the desired picture" (Valaskivi 2013, 491). As the CJAC has explicitly stated, the events of 3.11 fall into this category (for an example, consider the Creating a New Japan proposal which sought to restore "the shine of the 'Japan Brand"' (METI 2011, 1) in the wake of the disaster). Because these efforts often remain with the elite, they "might even be seen as futile by average citizens, who cannot see any connection between strategy documents and their daily lives" (Valaskivi 2013, 500). This perceived futility is illustrated in the distance between both the 'Recovery Olympics' and Cool Japan images that the national government is trying to foster on the one hand, and the actual social imaginary of 3.11 survivors expressed in the survey and interviews above, on the other. This is reiterated by Suzuki: "They have a feeling that through sports we can make people feel a little bit better and promote Japan's place in the world. Maybe that's what they should be trying to do, but I am pretty sceptical. I would much rather they confronted the realities head-on" (2017). ${ }^{26}$

\section{ABNEGATION}

Presumably to encourage approval of the 2020 Olympic bid, part of the Olympics rhetoric is the notion of having achieved a full recovery. Despite recovery not being achieved, that notion continues-for example, in 2016, Miyagi Governor Yoshihiro Murai was quoted as claiming "[Miyagi prefecture] managed to recover...in just five and a half years" (McKirdy 2016). Around the time of this quote, 150,000 evacuees were still living in temporary housing, including residents of Miyagi prefecture (Reconstruction Agency 2016, 10). An NHK poll of 1,000 survivors on the fifth anniversary of 3.11 observed that $53 \%$ believed "construction is going more slowly than expected" (NHK 2016). ${ }^{27}$ Of those in Murai’s Miyagi, 18\% "see no progress in the reconstruction of their hometown" (NHK 2016). In the Kahoku Shinpō 2018 survey, respondents rated the progress of recovery between $30 \%$ and $70 \%$, indicating that they still viewed the process as ongoing and incomplete seven

24「2020年に行われる東京オリンピックは、被災地の復興に役に立つと思いますか。」

25 「2020年に行われる東京オリンピックは、『復興五輪』との位置づけで誘致されましたが、『復興五輪』の理 念は明確だと思いますか。」

26 「スポーツの力でね、被災地を元気付けようとか、世界に日本の役割、あの、復興した様子を、見せようってい

う思いはあるんだろうけれども、今そういうことをすべきなのかなってのは疑問としてありました。もつと直視して 
As shown earlier, the Ganbarō Nippon initiatives in the immediate aftermath of 3.11 ushered in a 'resilient nationalism' which helped the national government to abnegate responsibility for assistance and recovery, and simultaneously alienated those affected (Shani 2016, 130). For the interviewees quoted above, and the participants in the Kahoku Shinpo survey, the Olympics' recovery rhetoric can be seen to abnegate responsibility in a similar way, by presenting an image of the disaster-hit areas that is at odds with residents' perceptions and experiences.

\section{Community or commodity}

Valaskivi observes that "the very act of perceiving the nation as a brand already changes the social imaginary of the nation as such: a country becomes an object of consumption" (2013,499; italics original). The nation is then "imagined as a commodity, rather than as a community" (Valaskivi 2013, 499). Community (both social and physical) is what people affected by the disaster in Tohoku seek. Commodity is the agenda of Cool Japan strategymakers. This distinction is central to the growing dissonance between those affected by 3.11 and the wider national agenda of political policy makers in Tokyo.

Despite the 2011 rhetoric linking Cool Japan to recovery, the final Cool Japan/ Creative Industries Policy Outline includes little reference to the disaster, or the realities in current-day north-east Japan (METI 2016). Not that it needs to: inbound tourism to the nation has grown, with Japan garnering over 28 million overseas visitors in 2017, compared with just over 6 million in 2011 (JTB Tourism Research \& Consulting Co. 2018). The Japanese government's pursuit of nation-branding projects and attendant rhetoric can therefore be seen as a relative success in the international context. Economic gains may be made by the nation as a whole, but because of competing demands on construction resources any post-Olympic economic gains appear unlikely to speed recovery.

\section{CONCLUSION}

A telling aspect of Abe's performance at the Rio Olympics was how shortlived the ill-fitting Super Mario costume was. Whether by design or error, Abe stood for less than a second before the costume was dramatically ripped off, revealing the truth: a politician dressed in a suit.

Considering Japan's rapidly increasing inbound tourism numbers, slick productions like the one at the 2016 Rio Olympic Games closing ceremony may convince outsiders that Japan is indeed very cool. But the government's pursuit of projects like the Olympics in the wake of 3.11 has effected change 
in the social imaginary and regional ideas of belonging due to a dissonance between those affected by 3.11 and other parts of the nation. There are two main sources of this dissonance. Firstly, concerns exist about the national government's pursuit of the Olympics delaying recovery in Tohoku. Secondly, people from affected areas are disappointed that their calamitous experiences are being deployed under a rhetoric of recovery to promote the event, which to date has had little to no positive impact on their recovery. As an exercise in nation branding, the Cool Japan Olympics are failing to influence a social imaginary in the nation-building context. To this end, Abe's assured smile at the Rio Olympics supported the government's Cool Japan agenda as a transnational nation branding effort. Yet, transfer him from the Rio Olympic arena to the tsunami-inundated and irradiated areas of Tohoku and very different perspectives emerge.

\section{APPENDIX: LIST OF INTERVIEWS}

Honma, E. 2014. Interview by author. Digital recording in Japanese. October 12. Honma, E. 2016. Interview by author. Digital recording in Japanese. June 24.

Kogure, H. 2014. Interview by author. Digital recording in Japanese. October 12. Kogure, H. 2018. Interview by author. Digital recording in Japanese. October 8. Komatsu, T. 2018. Interview by author. Digital recording in Japanese. October 4. Murakami, T. 2018. Interview by author. Digital recording in Japanese. October 4. Okano, S. 2017. Interview by author. Digital recording in Japanese. September 29. Suzuki, Y. 2017. Interview by author. Digital recording in Japanese. October 2. Suzuki, Y. 2018. Interview by author. Digital recording in Japanese. October 10.

Tsukamoto, T. 2017. Interview by author. Digital recording in Japanese. September 29.

\section{REFERENCES}

Abe, S. 2014. "Policy Speech by Prime Minister to the 187th Session of the Diet." Prime Minister of Japan and His Cabinet, 29 September. Accessed 10 January, 2019. https://japan.kantei.go.jp/96_abe/ statement/201409/policyspch.html. Japanese version accessed 14 January, 2019. https://web.archive.org/web/20141013155540/http://www.kantei.go.jp/ jp/96_abe/statement2/20140929shoshin.html.

Aldrich, D. P. 2017. "Trust Deficit: Japanese Communities and the Challenge of Rebuilding Tohoku." Japan Forum (29) 1:39-52. https://doi.org/10.1080/0955 5803.2016.1227350

Alexander, L. 2013. “Tokyo's Win Brings Fear That Tsunami Survivors Will Lose.” The Times, 9 September. http://www.thetimes.co.uk/tto/sport/olympics/article 3864107.ece.

Anderson, B. R. O'G. 1983. Imagined Communities: Reflections on the Origin and Spread of Nationalism. London: Verso.

Berry, J. 2013. "A Uniform Approach? Designing Australian National Identity at the Sydney 2000 Olympic Games." Journal of Design History 26 (1): 86-103. Accessed 29 January, 2019. https://doi.org/10.1093/jdh/eps016. 
Cabinet Office. 2014. Cool Japan Proposal. Accessed 16 January, 2019. https://www. cao.go.jp/cool_japan/english/pdf/published_document3.pdf.

.n.d. Cool Japan Strategy. Accessed 15 January, 2019. https://www.cao.go.jp/ cool_japan/english/index-e.html.

Chiba, Y. 2011. "24 Hours in Pictures." The Guardian, 10 April. https://www. theguardian.com/world/gallery/2011/apr/10/1.

Cleveland, K. 2014. “Significant Breaking Worse.” Asian Studies 46 (3):509-39. https:// doi.org/10.1080/14672715.2014.935137.

Daliot-Bul, M. 2009. "Japan Brand Strategy: The Taming of 'Cool Japan' and the Challenges of Cultural Planning in a Postmodern Age." Social Science Japan Journal 12 (2): 247-66. https://doi.org/10.1093/ssjj/jyp037.

Gamesbids.com. 2011. "Earthquake Topples Tokyo's Olympic Dreams For 2020," Gamesbids.com, 21 March. Accessed June 20, 2018. http://gamesbids.com/ eng/summer-olympic-bids/earthquake-topples-tokyos-olympic-dreamsfor-2020/.

Gutkind, L. 2012. You Can't Make This Stuff Up: The Complete Guide to Writing Creative Nonfiction from Memoir to Literary Journalism and Everything in Between. Boston: Da Capo Press.

IOC (International Olympic Committee). 2018. "Tokyo 2020 Makes Strong Strides Towards Hosting Transformative Games.” Olympic.org, 12 September. Accessed September 19, 2018. https://www.olympic.org/news/tokyo-2020makes-strong-strides-towards-hosting-transformative-games.

Iwabuchi, K. 2015. "Pop-culture Diplomacy in Japan: Soft Power, Nation Branding and the Question of 'International Cultural Exchange." International Journal of Cultural Policy, 21 (4): 419-32. https://doi.org/10.1080/10286632.2015. 1042469.

JTB Tourism Research \& Consulting Co. 2018. "Japan-bound Statistics," JTB Tourism Research \& Consulting Co. Accessed 29 October, 2018. https://www.tourism. jp/en/tourism-database/stats/inbound/.

Japan Property Central. 2016. "Rising Construction Costs are Starting to Affect Building Maintenance." Japan Property Central, 29 March. Accessed June 20, 2018. http://japanpropertycentral.com/2016/03/rising-constructioncosts-are-starting-to-affect-building-maintenance/.

Jiji Press English News Service. 2013. "Warming Up for Tokyo Olympics (5): Philosophy." Jiji Press English News Service, 23 September. Accessed June 20, 2018. http://search.proquest.com/docview/1434875414?accountid=12528.

Kahoku Shinpō [河北新報]. 2017. “Tōkyō kenbun-roku > seika rirē / hisai-chi o dashi gomen kōmuru [東京検分録>聖火リレー/被災地をだしごめん被 る]." Kahoku Shinpō, 16 July. Accessed 22 January, 2019. https://www. kahoku.co.jp/tohokunews/201807/20180716_73032.html. 
2018. 2018 Higashi-nihon daishinsai ankēto [2018年東日本大震災ア ンケート]. 11 March. Accessed 24 October, 2018. https://www.kahoku.co.jp/ img/news/pdf/shinsai_7years.pdf.

Komine, T. 2011. "Viewing the Economic Impact of the Great East Japan Earthquake." Discuss Japan-Japan Foreign Policy 6. https://www.japanpolicyforum.jp/ archives/economy/pt20110603163845.html.

Kurtenbach, E. 2014. "Construction Crunch Slows Japan Tsunami Rebuilding." Washington Examiner, 10 March. http://www.washingtonexaminer.com/ construction-crunch-slows-japan-tsunami-rebuilding/article/feed/2122787.

Lies, E. 2016. "Pain Lingers Five Years on as Tsunami-hit Japan Town Rises From Ruins." Reuters, 9 March. http://www.reuters.com/article/us-japan-disastergrief-idUSKCNOWBOWX.

Lindell, M. K. 2013. "Recovery and Reconstruction After Disaster." In Encyclopedia of Natural Hazards, edited by Peter T. Bobrowsky, 812-24. Dordrecht, Heidelberg, New York, London: Springer. https://doi.org/10.1007/978-14020-4399-4_285.

Martin, B. 2000. "Design Flaws of the Olympics." Social Alternatives 19 (2): 19-23.

Mainichi Shinbun [毎日新聞]. 2016. “Hasshin-bako-fukkō gorin to wa nani ka = Suyama Tsutomu [発信箱- 復興五輪とは何か=須山勉].” Mainichi Shinbun. 26 October. Accessed via Factiva, 21 January, 2019.

McGray, 2002. “Japan's Gross National Cool.” Foreign Policy, May/June: 44-54. https://doi.org/10.2307/3183487. https://foreignpolicy.com/2009/11/11/japansgross-national-cool/.

McKirdy, A. 2016. "Miyagi Governor Bullish on Hosting Olympic Events." The Japan Times, 12 October. http://www.japantimes.co.jp/news/2016/10/12/national/ miyagi-governor-confident-hosting-olympic-events-despite-negativemeeting-organizing-committee/.

METI (Ministry of Economy, Trade and Industry). 2011. Creating a New Japan: Tying Together 'Culture and Industry' and 'Japan and the World'. Accessed 18 June, 2018. https://web.archive.org/web/20110723025619/http://www. meti.go.jp/english/press/2011/pdf/0512_02b.pdf.

2016. Cool Japan / Creative Industries Policy. Accessed 18 June, 2018. http:// www.meti.go.jp/english/policy/mono_info_service/creative_industries/ creative_industries.html.

Morita, H. [森田 浩之]. 2017. “Fukkō gorin’ to iu kotoba ni, nuguikirenai iwakan ga waitekuru [「復興五輪」という言葉に、拭いきれない違和感が湧いてくる].” Gendai Bijinesu [現代ビジネス], 28 July. Accessed 21 January, 2019. https:// gendai.ismedia.jp/articles/-/52408?page=3.

Nagano, Y.2016. "Japan's Desolate Recovery from the Tsunami." U.S. News and World Report, 9 March. https://www.usnews.com/news/best-countries/articles/ 2016-03-09/in-japan-an-incomplete-recovery-from-the-tsunami. 
National Police Agency of Japan. 2018. Police Countermeasures and Damage Situation Associated with 2011 Tohoku District-Off the Pacific Ocean Earthquake, September 10. Accessed October 29, 2018. http://www. npa.go.jp/news/other/earthquake2011/pdf/higaijokyo_e.pdf.

NHK. 2016. "The Great East Japan Earthquake 5 Years On: A Survey of 1000 Survivors," NHK Online. Accessed June 20, 2018. http://www.nhk.or.jp/ d-navi/link/shinsai5/en.html.

Nikkei Inc. 2014. “Japan's Construction Costs at 21-year High.” Nikkei Asian Review, 16 July. Accessed June 20, 2018. https://asia.nikkei.com/Economy/ Japan-s-construction-costs-at-21-year-high.

NAIIC (Nuclear Accident Independent Investigation Commission). 2012. The Official Report of the Fukushima Nuclear Accident Independent Investigation Commission Executive Summary. Accessed 31 October, 2018. http:// dl.ndl.go.jp/view/download/digidepo_3514606_po_NAIIC_report_hi_ res4.pdf?content $\mathrm{No}=1 \&$ alternative $\mathrm{No}=$.

Reconstruction Agency [復興庁]. 2011. Zenkoku no hinansha-tō no kazu [全国の避 難者等の数]]. 24 April. Accessed June 20, 2018. http://www.reconstruction. go.jp/topics/120411hinansya.pdf.

. 2013. Zenkoku no hinansha-tō no kazu [全国の避難者等の数]. 25 October. Accessed January 22, 2019. http://www.reconstruction.go.jp/topics/maincat2/sub-cat2-1/20131025_hinansha.pdf.

2016. The Road to Recovery: Recovery and Reconstruction from the Great East Japan Earthquake. Accessed June 20, 2018. http://www.reconstruction. go.jp/english/topics/Progress_to_date/pdf/201609_The_Road_to_ Recovery_E.pdf.

2017. Zenkoku no hinansha-tō no kazu [全国の避難者等の数]. 28 March. Accessed June 20, 2018. http://www.reconstruction.go.jp/topics/main-cat2/ sub-cat2-1/20170328_hinansha.pdf.

. 2018a. Zenkoku no hinansha-tō no kazu [全国の避難者等の数].” 29 May. Accessed June 20, 2018. http://www.reconstruction.go.jp/topics/main-cat2/ sub-cat2-1/20180529_hinansha.pdf.

. 2018b. Zenkoku no hinansha-tō no kazu [全国の避難者等の数].” 28 September. Accessed October 29, 2018. http://www.reconstruction.go.jp/ topics/main-cat2/sub-cat2-1/20180928_hinansha.pdf.

Samuels, R. J. 2013. 3.11: Disaster and Change in Japan. Ithaca: Cornell University Press.

Shani, G. 2016. "Ganbarō Nippon: Human Insecurity, Resilience and National Identity After 3.11." In The Consequences of Global Disasters, edited by A. Elliott and E. L. Hsu, 129-40. Abingdon and New York: Routledge.

Taylor, A. 2011. "Japan Earthquake: The Long Road to Recovery." The Atlantic, 15 April. Accessed 29 October, 2018. https://www.theatlantic.com/ photo/2011/04/japan-earthquake-the-long-road-to-recovery/100047/. 
Taylor, C. 2004. Modern Social Imaginaries. Durham: Duke UP. https://doi. org/10.1215/9780822385806.

TMG (Tokyo Metropolitan Government). 2016. See you in Tokyo and Tohoku 2020. YouTube video, posted 27 April. Accessed October 24, 2018. https://www. youtube.com/watch?v=DVzUf2lW3wk\&feature=youtu.be.

. 2018. See you in Tokyo and Kumamoto 2020. YouTube video, posted 18 February. Accessed October 24, 2018. https://www.youtube.com/ watch?v=o2UJL2vxU-I\&feature $=$ youtu.be.

Tomlinson, A. 2014. "Olympic Legacies: Recurrent Rhetoric and Harsh Realities." Contemporary Social Science 9 (2): 137-58. https://doi.org/10.1080/21582041 .2014.912792.

United Nations. 2005. Resolutions Adopted by the General Assembly A/RES/60/1. Accessed June 20, 2018. http://www.ifrc.org/docs/idrl/I520EN.pdf.

Valaskivi, K. 2013. "A Brand New Future? Cool Japan and the Social Imaginary of the Branded Nation." Japan Forum 25 (4): 485-504. https://doi.org/10.1080/ 09555803.2012.756538.

Willacy, M. 2013. Fukushima: Japan's Tsunami and the Inside Story of the Nuclear Meltdowns. Sydney: Pan Macmillan.

Wilson, J. 2016. Rio 2016: Closing Ceremony. Television broadcast, Channel 7 (Australia). 22 August. 